Received September 21, 2009

Revised November 5, 2009

Accepted November 18, 2009

\title{
The International States Systems Since 1648 and Small States 'Systemic Resilience'
}

\author{
MATTHIAS MAASS ${ }^{*}$
}

Since 1648 , the number of small states has varied significantly. There have been more than one "rise and fall" in the number of small states. This study begins a broader analysis into causality by investigating this phenomenon. By setting out the changes in the composition of the international states system since its inception in its modern form with the Peace of Westphalia, the study intends to discuss the proliferation of small states over time as a significant phenomenon in the history of international relations. The study then continues by linking the changes in the number of small states to major systemic changes, arguing that different types of states system correspond to different levels of "systemic resilience" of small states.

Keywords: Small states, World History, State resilience, State vulnerability, Small state proliferation, International states system, Westphalian states system, Balance-of-power 


\section{I . INTRODUCTION}

\section{Question and method}

C

onventional wisdom has it that a few decades ago small states rose dramatically in numbers. Consequently, it is believed, we live in a world with unprecedented numbers of small states today. This paper challenges this viewpoint, laying out a historical perspective that demonstrates how small states at times populated the states system in even higher numbers than today, but have also counted much lower at different times. Moreover, this paper suggests that the cause for the resilience (or lack thereof) of small states in the states system might not only be found by looking at the states' capabilities, but may be located at least in part at the structural level of international relations. In short, the question is about how resilient the small state has been over time, and how such resilience may be related to the structure of the international states system.

This study here connects with and expands on the few studies on small states, taking a long-range point-of-view (Henrikson 1999; Enriquez 1999). Moreover, there has been little data available that specifies how many small states existed historically. Morgenthau (1967), for example, comments on the decline in the number of small states, but rather in passing. Available data-sets like the Correlates of War Project have a limited time-horizon and are not concerned with small states (Singer and Small 1972). Most of the studies of small states are concerned with particular issues that may strengthen the small state and improve its foreign policy effectiveness. Studies on the "vulnerability" and "resilience" are prime examples (Commonwealth Advisory Group for Updating the Vulnerability 1997; Kisanga and Dancie 2007; Briguglio et al. 2008). This paper will expand on this work by first adding a longer-range perspective on the fate of the small state in international relations, and second by reversing the angle, in a matter-of-speaking, and investigating a possible match of the survival of small states and major structural changes of the states system.

In short, this study presents a long-term investigation into the 'fate' of the small state, and applies a primarily structural approach as analytical framework. The objective is to identify major trends, if any, in the changes of the number of states over time and investigate if these match with broad structural changes and major stages of the international states system. The argument advanced is that these dimensions exhibit indeed an analytically significant degree of linkage.

However, I will not provide a full-fledged correlation analysis here. First, the available data does not allow it since only one variable is available (the number of states) and the other aspect (the states system) does not lend itself to being expressed in the form of proper variables. Second, the intended focus of this study is to set out a historical picture and analytically frame it in systemic 
terms. Therefore, I must delay more specific correlation analyses until later.

\section{Framework and terms}

The analytical framework for this systemic analysis of small states is the international system in its whole temporal dimension, i.e., from the inception of this particular international system in 1648 , when the so-called Westphalian states system was widely implemented for the first time and had reached a sufficient level of maturity, to the early $21^{\text {st }}$ century (Gross 1948; Horsman and Marshall 1994). Moreover, the analytical focus of this study is not the global environment per se, but only a particular states system, the Westphalian states system, which developed from a geographically restricted, European system in the $17^{\text {th }}$ century to a truly universal one in the $19^{\text {th }}$ century. In connection with this, it is important to point out that I am only concerned with those states that were part of this particular system. While the existence of other states outside this system and at various times in history is fully acknowledged, these states were not units of this particular Westphalian system and were not counted until they joined the states system. For example, many African territories, even those with many state-like features, were not part of the European-dominated Westphalian states system before they were colonized. However, once the former colonies became independent states during the period of Decolonization in the second half of the $20^{\text {th }}$ century, they were entered into the data set on which this study is built.

Since the focus here is the international system, any statistical analysis has to include all those units that actually make up the system. Whether a particular unit passes today's formal requirements of statehood is secondary to the question of whether this unit was in fact functioning as a state in the system at a particular time. This is best illustrated by two examples. Today, full recognition as a state in the legal sense is widely withheld from Taiwan. Although it fulfills the minimum requirements for statehood of the 1933 Montevideo Convention and of Customary International Law, full diplomatic recognition is being with held from Taiwan for political reasons that have to do only with Chinese politics (Hughes 1991). However, for all practical purposes, Taiwan functions in the international states system as a state. At the same time, in the past some organizations featured a number of attributes of statehood but still did not achieve the status of a unit of the states system. In the $17^{\text {th }}$ century, the Dutch East India Company, for example, had general control over a territory (the Indonesian archipelago), was tightly governed, and even had the right to declare war and make peace, as well as to coin money and establish additional colonies (Shennan 1995). Despite these characteristics, however, the Dutch East India Company was never regarded as a state-like unit of the international system and never performed the role of a systemic unit. While the Dutch East India Company 
cannot be counted as a small state, Taiwan must be regarded as one in this study.

For small states, their size is the defining characteristic. However, there is no clear-cut definition of what it means to be a small state, and neither is there a precise understanding what exactly distinguishes a small state from a non-small state. In addition to the questionable "fruitfulness" of such an endeavor of developing such a theory (Griffiths and Pharo 1995), Henrikson has pointed out that too restrictive a definition might run the risk of losing "fullness of understanding" (Henrikson 2001). Ultimately, the problem is one of complexity. Various overlapping and interdependent factors jointly contribute to our understanding of a state's size (Maass 2009).

However, because of the systemic focus of this study, it is not the physical size of the state, for example its territory, but rather the state's size relative to the other states in the international system, that matters here. In fact, when looking at the states system in particular, a crucial element of size is its relativity: A small state is only small when compared to a non-small state. The term "contextual" has been used also to describe essentially the same idea, i.e., the fact that smallness must be understood and analyzed in the context of the environment (Hafiz and Khan 1987). For a contemporary viewpoint, see Pufendorf's seminal work (Pufendorf 1934). Henrikson advanced the discussion about the relativity of size by pointing out the need to distinguish between "absolute" size (i.e., size that can be measured by clearly quantifiable criteria) and "relative" size (i.e., size that needs to be seen in relation to the relevant environment). Henrikson rightly favors and applies the later notion of size in his earlier study of small states (Henrikson 1999).

For these reasons, this study uses a concept of "systemic smallness" according to which a small state is defined by its size within the context of the contemporary states system: A "small state" is defined as a systemically small unit of the international states system. As far as this study is concerned, small states must fulfill the following requirements as explained below.

First, the state must have a population of fewer than 25 million today. If the population is over 15 million people, the states perceived structural position as a small state or not will be decisive. Second, the size of states is conceptualized in relation to the overall states system. What qualifies as a small state with just a few million inhabitants today might have amounted to great power status 300 years ago. Third, a state is considered as such for the purpose of this study if it has been considered a legitimate member of the states system at the time; formal and contemporary requirements of statehood (such as in the 1933 Montevideo Convention) are not decisive. Fourth, small state resilience is investigated in a systemic context only here. For analytical purposes, this system consists of states only and grew from a European-centered system after 1648 to the universal system of today; during the course of its existence, however, 
its critical features remained in place, allowing for an analysis of "the" Westphalian system, 1648 to today.

In order to identify those states that are considered small according to these criteria, the following approach was applied. In the first step, the criterion of population size of states was used to cut down the list of possible small states. All states that have a population of less than 25 million people were considered candidates for small statehood. All states that have a population of fewer than 15 million people were considered small states. In the second step, states that have a population of between 15 and 25 million people were studied in more detail, and a decision whether or not a state could be counted as small was made on a case-by-case basis. The deciding criterion was whether the candidate considered itself and was considered by the international community of states to be small in relation to the overall states system.

The case of Australia illustrates this process: Today, Australia has a population of just over 20 million people, and thus qualifies as a potential small state. However, Australia is neither perceived to be a small state-but rather consciously as a middle power-nor does it perceive itself as a small state-in contrast to its neighbor New Zealand for example. As far as Australia as a unit in the international system of states is concerned, Australia is too big to belong to the group of small states. Hence, Australia was not counted as a small state for the purpose of this study.

While this approach proved feasible for the current time period, it had to be adjusted to cover earlier periods of time. Not only does population data become more unreliable and scarce the further back in time the research stretches, but the upper population cut-offs also would have to be corrected downward in order to account for global population growth. For this reason, the small state of the late $20^{\text {th }}$ to early $21^{\text {st }}$ century was seen as a model, and its state size vis-à-vis the overall state system was projected back in time with the decisive criterion again being whether the particular state saw itself and was perceived by the contemporary international community to be in fact small in relation to the total state system. Only small states that were seen as such by their fellow states at the time of their existence qualified as small states for this study.

This qualitative standard for small states and a case-by-case investigation is the only feasible approach that captures the small state over the course of history and throughout the entire states system. What is more, this approach is sufficiently flexible for this purpose, but far from arbitrary. Arguably most importantly, few borderline cases of states that could be counted as either small or not small had to be considered. In fact, for the vast majority of cases, the decision of how to categorize the state, either based on its population or on its perceived systemic size, was clear-cut. However, the following data and graphs lay no claim to absolute precision, since it is recognized that some variation in categorizing 
the states is possible. Since the purpose of this study is to identify and explain the overall trends in the survival and proliferation of small states, a degree of variation does not undermine the findings, however.

In order to analyze the changing role of small states in the international system, it is paramount to 'filter out' any changes simply caused by the expansion of the system and the resulting increased membership in the system. During the more than 360 years of its existence, the international states system has seen a major geographic expansion. From its European core in the $17^{\text {th }}$ century, the system spread to other parts of the globe and is today the global-universal state system. Since such geographic enlargement might distort the analysis of small states proliferation, the Small States Index (SSI) was added to the data in order to capture the relative number of small states in the whole states system. The SSI gives the proportion of small to non-small states, i.e., the total of small states divided by the number of non-small states. Giving the proportional figures of small states and non-small states, it is as a tool to identify the relative number of small states within the international system of states. Thus, it becomes possible to analyze small states proliferation over time in spite of the geographic expansion of the international system of states.

\section{The data set and periodization}

The data presented here have been derived from a specialized data set. Since no appropriate data-set that covers the whole period 1648 to today and that categorizes states according to their size is available, a specialized data-set needed to be put together. More information about the data-set, in particular the sources used and the methodology applied, is provided elsewhere (Maass 2003). The complete data set can be accessed at http://www.mmaass.net/research.htm

The data set covers 360 years and thus major events in world history. Therefore, sub-dividing the data into different periods is appropriate. Moreover, such periodization will serve as an interpretive tool, demonstrating that it is indeed possible to identify certain trends in small states proliferation over the course of time. Also, sub-dividing the data into a number of periods allows for considering major watersheds in the history of the international states system. A cursory glance at the data (see Graph 1, "Small States and Non-Small States, 1648-2009" below), suggests that in particular the French Revolutionary Wars at the turn of the $18^{\text {th }}$ century and Italian and German national unifications in the second third of the $19^{\text {th }}$ century were periods of extraordinary decline in the number of small states. Proper periodization allows for preventing a distortion of the broader and more long-term trends by these singular events.

The Napoleonic Wars and the First World War mark major shifts in the world history and international relations. Therefore, the data are broadly sub-divided into the following periods. The first era spans from the Peace of Westphalia 
1648 to the beginning of the French Revolutionary Wars in 1792. It is followed by a period lasting from the Congress of Vienna 1815 to the outbreak of the First World War in 1914. The third period then extends from the Paris Peace Treaties 1919 to today. These larger periods have been broken down further where deemed necessary to take significant events into consideration and to open the view on broader trends of the proliferation of small states. In particular for the $20^{\text {th }}$ century, a sub-division into the first half and second half of the Cold War era seems appropriate; this is reflected in the numerical and qualitative discussion below.

\section{Overview}

Graph 1, "Small States and Non-Small States, 1648-2009" shows the development of the numbers of small states and of non-small states since 1648 . Over the course of more than three and one-half centuries since the Peace of Westphalia, the number of small states and of non-small states has fluctuated, at times dramatically.

GRAPH 1: Small States and Non-Small States, 1648-2009

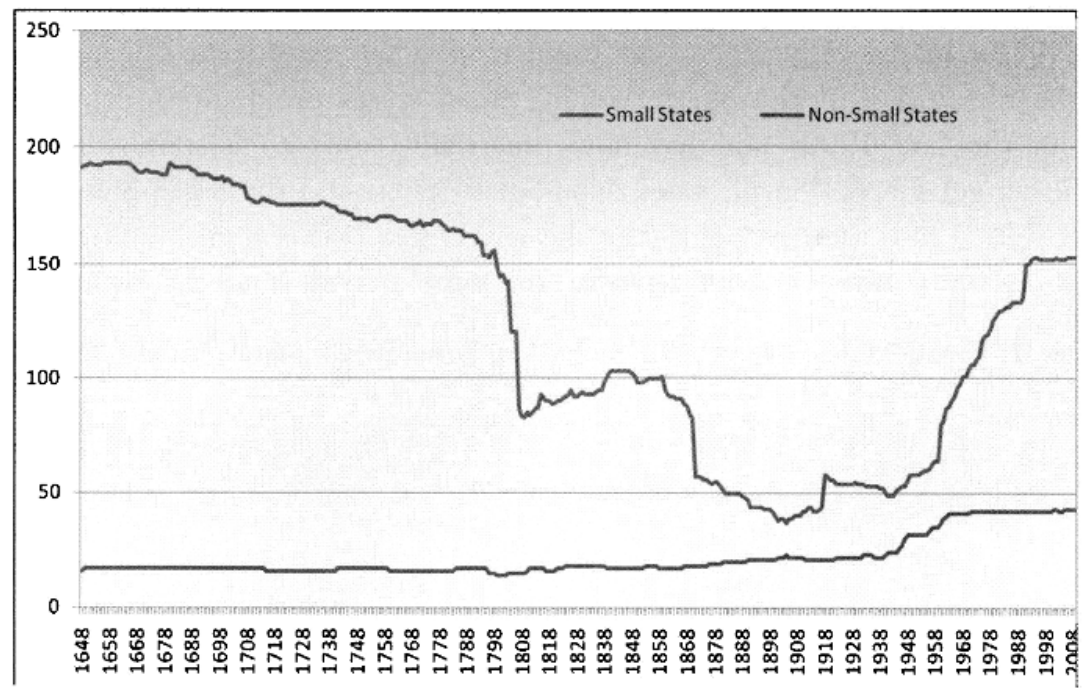

When the development in the number of small states is sub-divided into the three major phases just outlined, markedly different trends with respect to the proliferation of small states can be identified for each major period. A first phase in the numerical development of small states can be identified as lasting from the Peace of Westphalia in 1648 to almost the end of the $18^{\text {th }}$ century. This period was characterized by an overall slow but steady decrease 
in the number of small states, with periods of decline repeatedly being interrupted by times of relative stability. This first phase ended with a sharp overall decline in the number of small states, beginning in the 1780s, accelerating through the 1790s, and most dramatically during the early 1800s, when Napoleon Bonaparte was establishing French hegemony over most parts of Western and Central Europe.

The second major period began in 1815, after the final defeat of Napoleon. During the following three decades, the number of small states rose again slowly until slightly over 100 small states existed again in 1841. After a period of stabilization in the number of small states during the $1840 \mathrm{~s}$ and $1850 \mathrm{~s}$, the numbers sharply decreased again. The sharpest drop occurred between 1859 and 1872, when the Italian and German nation states were created out of a considerable number of small states. The all-time low was reached in 1905/06 with only 38 small states in the international system. This period ended with the outbreak of the First World War

The third phase in the historical development of the numbers of small states began with a pronounced increase in 1918/1919, followed by stable period, before the number of small states declined again as Germany occupied large parts of Europe in the 1940s. After 1945, however, the number of small states rose exponentially, in particular during the era of Decolonization in the 1960s and 1970s. In the early 1990s, the number of small states spiked again, caused by the dissolution of the Soviet Union. Small states proliferation came to an end in the late 1990s and has now practically come to a standstill.

The second graph, "Small States, Non-Small States, and the Small States Index, 1648-2009," adds the development of the relationship between small and non-small states as both numbers' quotient for the time period 1648 to 2009 .

GraPH 2: Small States, Non-Small States, and the Small States Index, 1648-2009

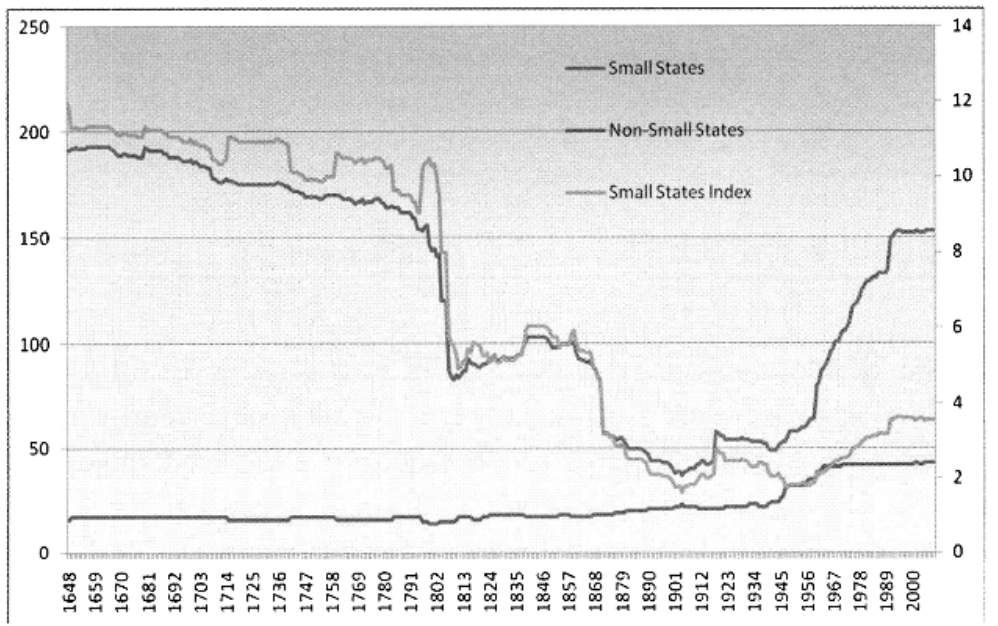


The SSI parallels the absolute number of small states closely. However, the rapid proliferation of small states during the third and fourth quarters of the $20^{\text {th }}$ century appears less dramatic when expressed in relative terms: During this period, not only were new small states created, but non-small states were also added to the system. The system witnessed an overall expansion of units.

Moreover, the long-range historical perspective also points toward the fact that the current number of small states-absolute as well as relative-is neither unprecedented nor out of the ordinary. The current total number of small states is well within the system's historical maxima. In fact, historically speaking, the SSI remains at its lower end at the beginning of the $21^{\text {st }}$ century.

\section{Three Distinct Phases of Small State Survival}

\section{Phase I: Small states from Westphalia to the French Revolution, 1648-1791}

For more the than 150 years since the Peace of Westphalia, the number of small states fluctuated considerably, as Graph 3, "Small States, Non-Small States, and the Small States Index, 1648-1791," below indicates. This period also saw periods of stability and was marked overall by a slow, gradual decline. As suggested by the high number and proportion of small states during this period, small states proved largely resilient to threats to their existence. For the second half of the $17^{\text {th }}$ century and the $18^{\text {th }}$ century, small states, the large and overall fairly stable number and the high proportion of small states suggest that during this period they remained to a considerable extent resilient to external forces that threatened their survival.

GrapH 3: Small States, Non-Small States, and the Small States Index, 1648-1791

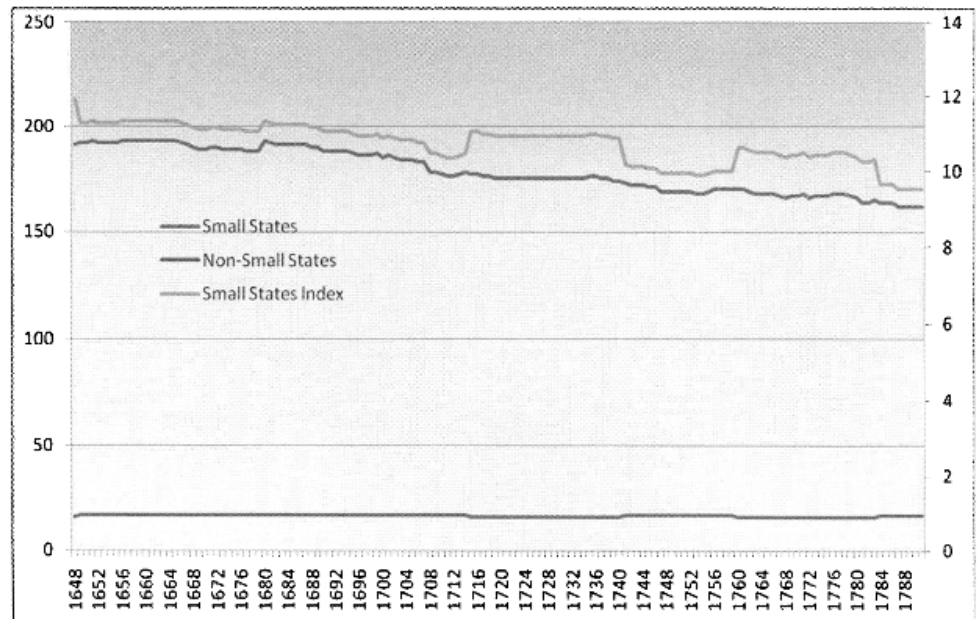


As Graph 3, "Small States, Non-Small States, and Small States Index, 1648-1791" above illustrates, the overall number of small states as well as the SSI both dropped slightly but steadily over the course of over six decades after the Peace of Westphalia. After the end of the Thirty Years War, 191 small states existed, and in 1715, the year of Louis XIV's death, 177 small states still existed, a decline of 14 states, or 7.3 percent of the total. Since the number of non-small states remained stable over the same time period, the SSI followed the overall trend of the small states numbers: The overall trend of the SSI for the whole period of time is one of a slow, but steady decline, falling from 11.9 to 11.1 small states per one large state until 1715 .

\section{Phase II: Small states from Vienna to Sarajevo, 1815-1914}

After Napoleon's quest for the domination of Europe had been finally beaten back in 1815, a new international structure was put in place (Luard 1968), when, at the Congress of Vienna, the Concert System was implemented.

How did the small state fare during the concert system of the $19^{\text {th }}$ century? Are small states in a concert system not only "second-tier" units but also its primary victims? At the outset, it can be observed (see Graph 4, "Small States, Non-Small States and the Small States Index, 1815-1914," below) that a dramatically declining number of small states during this era suggest that in the $19^{\text {th }}$ century, small states proved much less resilient to threats to their survival than during the previous one and one-half centuries. Over the course of the $19^{\text {th }}$ century, the number of small states-in absolute terms and relative to the larger states-decreased sharply.

GraPH 4: Small States, Non-Small States, and the Small States Index, 1815-1914

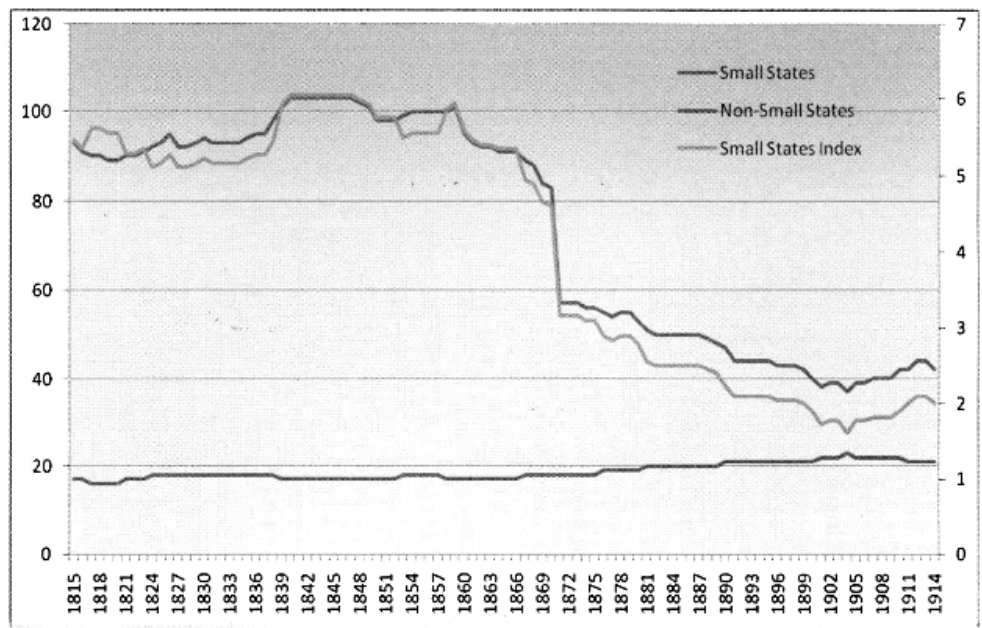


As in the previous era, the number of non-small states did not experience sudden changes. Their numbers increased slowly, however, from 16 in 1817 (their lowest point) to 22 non-small states (their maximum in this period) in 1904. In contrast to such relative stability over the course of almost 100 years, the number of small states dwindled from 93 in 1815 to 42 in 1914 . However, even more dramatic is the decrease in the number of small states if the brief period of proliferation before the First World War is discounted: Just over one decade before the war, in 1901, the number of small states had reached its all-time low with only 38 surviving small states in the international system. Their number relative to the number of non-small states had fallen to 1.6, also a historic low, by 1904 .

During the period immediately following the Congress of Vienna a marked volatility with respect to the number of small states can be identified. Short recoveries in their number were frequently punctuated by drops which limited the overall recovery of the number of small states in the first half of the $19^{\text {th }}$ century. A series of recoveries and declines continued until a somewhat more substantial recuperation in the number of small states began in 1839, bringing the total number to just over 100 in 1840 . Immediately afterwards, however, the numbers leveled off before again starting to decline by the end of the following decade.

The second half of the $19^{\text {th }}$ century has proven to be a "very unattractive political world" for small states (Rothstein 1968). The numbers most certainly bear this out: In the second half of the $19^{\text {th }}$ century, the number of small states collapsed in two stages. First, an unprecedented fall cut the number of small states almost in half between 1859 and 1871. In only twelve years, the SSI fell by almost two thirds, from 5.9 to 3.2 , indicating a major change in the composition of the international states system. This was largely due to the national unifications of Germany and Italy and to Italian and German nationalism. Second, the decrease in the number of small states continued into the $20^{\text {th }}$ century, even if at a reduced rate. In the last quarter of the $19^{\text {th }}$ century, the number of small states dropped about 30 percent again. Over the same period of time, the relative number of small states fell equally sharply, from about 3 to just under 2 .

On the whole, the experience of the small state during the $19^{\text {th }}$ century was a negative one with respect to their resilience to threats to their survival. Except for a short period of recuperation, the decline in the number of small states that had already begun in the previous era was at times dramatically accelerated. Towards the end of the $19^{\text {th }}$ century, the number of small states reached its all-time low. 


\section{Phase III: Small states in the $20^{\text {th }}$ century}

I subdivided the $20^{\text {th }}$ century into three periods. The first phase starts in 1919 with the creation of the League of Nations and spans what has now become known as the "Interwar Period." The second phase, which began in 1945 , tilted quickly towards bipolarity between two superpowers during the so-called "Cold War," which ended in 1991 (Luard 1968). The third and final phase is the post-Cold War period, followed by US hegemony. The development of the number of small states in the $20^{\text {th }}$ century, is summarized in Graph 5, "Small States, Non-Small States, Small States Index, 1919-2009" below.

GRAPH 5: Small States, Non-Small States, and the Small States Index, 1919-2009

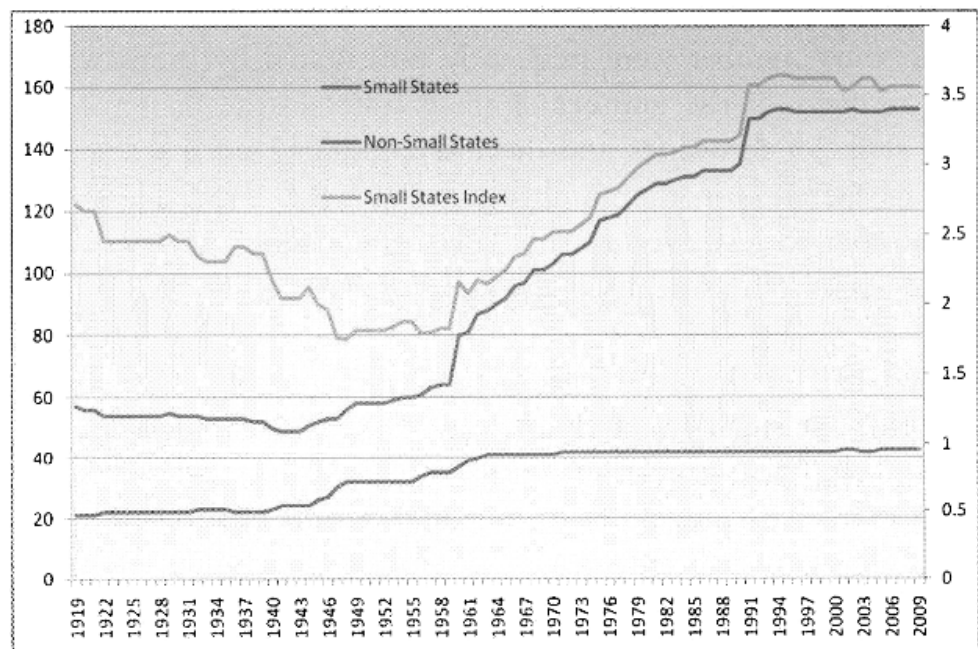

Immediately after the Treaty of Versailles the number of small states remained comparatively stable, both in absolute terms (between 1919 and 1937, the total number was reduced by only four small states) and relative to the total number of states (the SSI fell only from 2.7 to 2.4 in the same time period). The time immediately following World War II was marked by a steep increase in the number of small states that took place during the four and one-half decades of the Cold War. Had the international system included only 52 small states in 1945 , in 1991, the number had almost tripled to 150 small states. Due to the simultaneous but much less pronounced rise in the number of non-small states, the SSI increased less sharply, but with almost 80 percent during the same time period still substantially. After the end of the Cold War, the small states curve, the ones based on total as well as relative numbers, moved up only slightly and have stayed effectively flat since 1996. Moreover, despite the modest increases in the late 1990s, the SSI has remained well under the mark of four. 
(1) The interwar period

Graph 6 "Small States, Non-Small States, Small States Index, 1919-1938" below depicts the development of the number of small and non-small states, as well as the changes in the SSI number for the interwar period. The number of small states jumped from 44 in 1917 to 57 only two years later. Since the number of non-small states remained stable during these three years, the proportion of small states in the international states system rose in parallel and similarly significantly from 2.1 to 2.7 in the same three-year time span.

GraPh 6: Small States, Non-Small States, and the Small States Index, 1919-1938

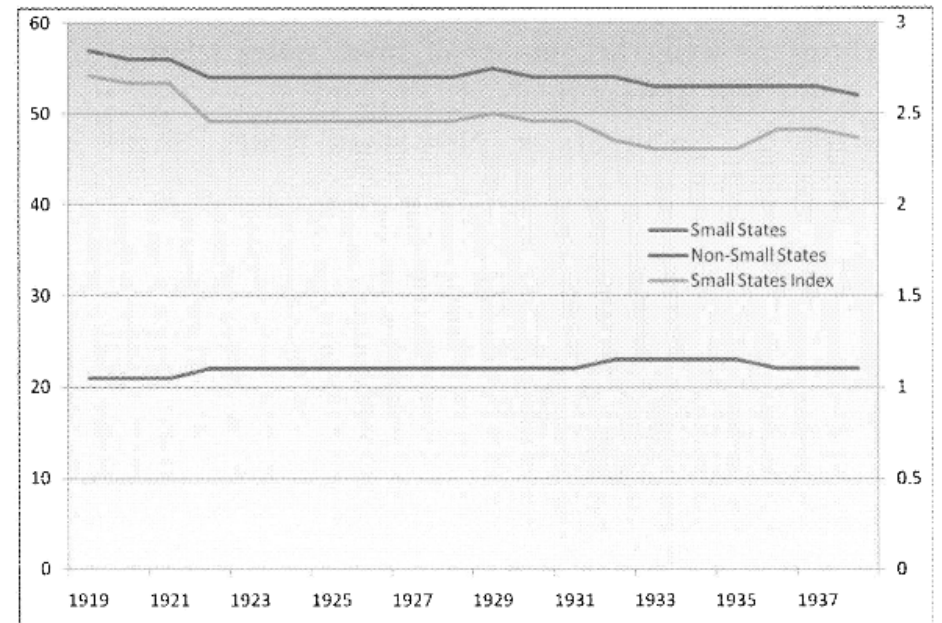

This initial rise in the number of small states was due primarily to the implementation of the principle of national self-determination and the break-up of empires such as the multi-ethnic empire of Austro-Hungary, which was replaced by a number of newly independent states in 1919. By the late 1930s and early $1940 \mathrm{~s}$, the international environment had changed drastically, not the least for small states: The system of collective security had collapsed and empires were being built. Rothstein argues that this period was probably the most "unattractive one" for the small states in the 20 $0^{\text {th }}$ century (Rothstein 1968). While the international states system counted 57 small states in 1919, the number had declined to only 52 small states 20 years later and to 49 in 1941 . While this marked a drop of 14 percent between 1919 and 1941 , the share of small states of the overall number of states dropped even further, by nearly 26 percent, over the same period of time. 


\section{(2) The Cold War}

A second major phase of the $20^{\text {th }}$ century began with the end of the Second World War in 1945 and lasted until the end of the Cold War in 1991.

After the Second World War, and in particular beginning in the late 1950s, the number of small states increased dramatically by any standard. In 1945, only 52 small states existed, but ten years later, that number had already increased to 60 small states. Another decade later, their number had reached 92, and in 1975 , the number of small states stood already at 117 . However, the proliferation continued, and by the middle of the 1980s, the number of small states had risen to 131 , only to reach the maximum of this period with 150 small states in 1991. Although the number of non-small states rose during the second half of the $20^{\text {th }}$ century as well, the number of small states relative to the number of non-small states still almost doubled, climbing from 2 in 1945 to 3.6 in 1991. See Graph 7, "Small States, Non-Small States, Small States Index, 1945-1991" for an illustration.

GraPH 7: Small States, Non-Small States, and the Small States Index, 1945-1991

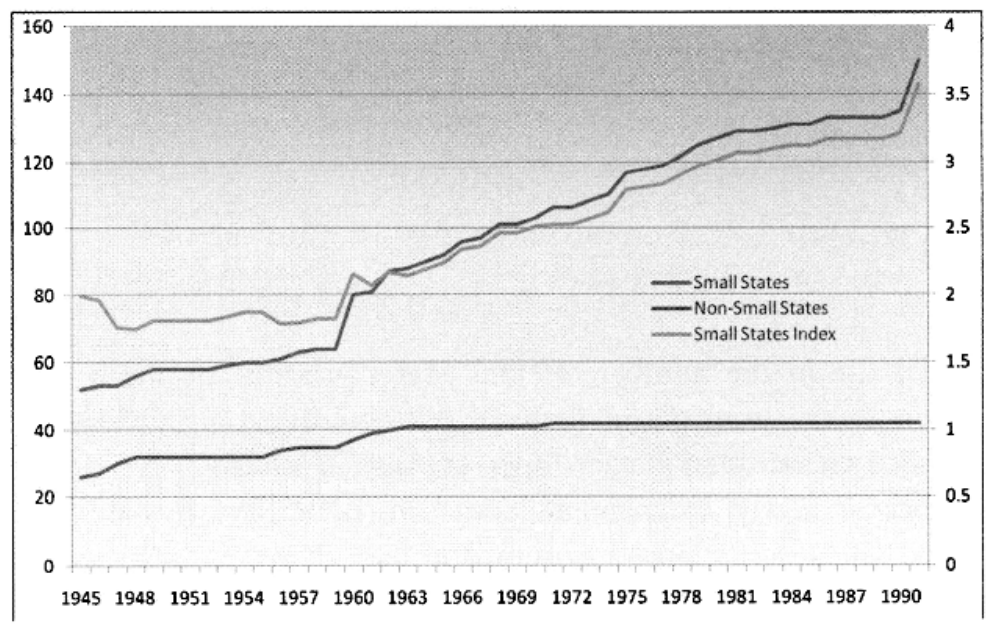

To be sure, decolonization of the $1960 \mathrm{~s}$ in particular caused the addition of numerous new small states. More often than not, these states had been former colonies of European states and had secured their own independence with increasing speed after the end of the Second World War. The result in terms of the number of small states during the period of decolonization in the 1960s and 1970 s was truly remarkable. While the states system included only 64 small states in 1959, that number had skyrocketed to over 100 a decade later and had reached 127 small states by the end of the 1970s. Parallel to this increase in absolute numbers, the number of small states relative to the number of 
non-small states jumped from 1.8 to 3 over the course of these two decades, indicating a dramatic shift in the overall composition of the international states system.

The Cold War ended with a further spike in the number of small states as the Soviet empire collapsed. The immediate results were the creation of new small states in the periphery around Russia.

\section{(3) Post-Cold War and US hegemony}

After the initial jump in the number of small states right after, or one might say "with," the end of the Cold War, the number of small states soon stabilized (see Graph 8 "Small States, Non-Small States, and the Small States Index, 1992-2009"). The break-up of the former Yugoslavia and the split of Czechoslovakia added a few more small states. In 2009, the number of small states stands at 153 with non-small states totaling 43. Today, for each non-small state, 3.5 small states exist. While that is a low number if compared to the historic highs of the SSI in the $17^{\text {th }}$ century, it expresses a significant majority of small states in the contemporary states system. Graph 8, "Small Sates, Non-Small States, and the Small States Index, 1992-2009" summarizes the picture during the recent one and one-half decades.

Today's international system appears to support a high number of small states. While the development has flattened and proliferation has, for all practical purposes, come to a halt, the number of small states appears stable. It seems that the current international system supports the existing high number of small states but is not leading to the addition of new small states to the system.

GraPH 8: Small States, Non-Small States, and the Small States Index, 1992-2009

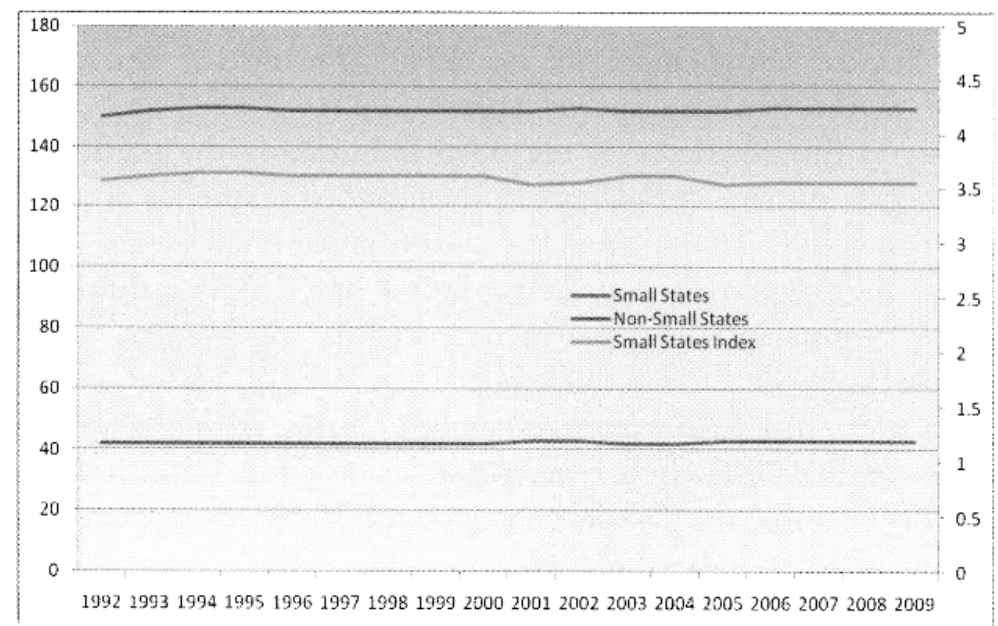




\section{Small States "Systemic Resilience" Over Time}

As the discussion above indicates, changes in the number of small states match the major changes of the international states system-the major phases of the international system of states and the shift from one to its successor. The international system appears to be a significant factor impacting on the structural resilience, understood as the survival or proliferation of small states. In fact, a critical causal dynamic in this context seems to be that changes in the states system translate very strongly to changes in the security environment of small states. To be sure, the survival and proliferation of small states is not only determined by the states system. Various other factors, both, at the systemic and sub-systemic levels, come into play. However, what is maintained here is that the states system is one significant factor that impacts on small states resilience to threats to their survival.

During the first phase, 1648 to 1791 , the international states system under investigation was characterized by the balance-of-power. As the high total number of small states, both absolute and relative to non-small states, during this time period suggests, this particular type of states system proved to be rather beneficial to the survival of small states. Put differently, in this environment, small states had considerable systemic resilience.

There is theoretical and historical evidence to support this observation. In the balance-of-power, small states should be able to leverage other states' resistance to major territorial ambitions of rising hegemon's to their advantage. Put differently, great powers may be prevented from usurping small states because other great powers will oppose them in order to maintain the overall balance-of-power. In fact, historical evidence backs up this claim. In 1715, for example, Victor Amadeus II of Savoy-Piedmont succeeded in resisting Austrian designs to take over his territory by drawing France in and reminding Paris that Austrian ambitions had to be checked not so much for his (Victor Amadeus') own sake, but in the interest of the balance-of-power (Black 2002).

In contrast to the experience of the small state during the previous era, the balance-of-power system, during the $19^{\text {th }}$ century, the number of small states collapsed dramatically. The international states system had changed into a concert-system, which afforded the small state little if any chance to develop systemic resilience to a meaningful degree. In fact, in this environment, small states resilience to security threats was undermined significantly, and as an immediate result, small states disappeared in large numbers. Again, theoretical and historical insights support this claim. In a concert-system, the great powers, the so-called concert powers, equate the system's interests with their own interests. In this situation, small states under threat cannot invoke a larger logic of the system anymore to get one great power to oppose another one in its territorial ambitions. In short, structurally, their resilience is limited severely. 
The case of Belgium is a case in point: In 1815, the concert powers resisted a strong desire among the Belgian people to have their own state. A strong Netherlands that included the Belgian territory was deemed too important as a check against a possibly resurging France. However, by 1830 the situation had changed and France had extended considerable influence into its northern neighbor. Now, an independent and anti-French Belgium was deemed in the concert powers' interest and was indeed created. In short, small states were largely at the mercy of the concert powers' interests. For most of the small states, that meant a severe limitation of their resilience to threats to their security during the $19^{\text {th }}$ century.

With the end of the First World War, the international system of states changed again. Early in the Interwar Period between the two World Wars, the principles of national self-determination and collective security were introduced. This, together with the newly found League of Nations as a new instrument of diplomacy, worked in the small states favor. In fact, some European small states developed an almost symbiotic relationship with the concept of collective security as their prime benefactors and chief advocates at this time. The principle of self-determination also benefitted them, not just justifying the dissolution of some empires such as Austria-Hungary, but also legitimizing the claim to statehood by existing small states. The League of Nations, too, contributed to an international environment that strengthened the small state, because with the institution, a premium was put on diplomacy and negotiation, not on power, strength, and state size. As long as this international environment held, small states benefited again from how the system operated. Once again, the international states system provided small states with the opportunity to upgrade their systemic resilience in a substantial way. Consequently, the 'survival rate' of small states stabilized, which was reflected in their numbers remaining quite stable.

Unfortunately, this situation was short-lived, and the Second World War produced a new and different international states system altogether. While the principles of self-determination and collective security were not completely abandoned after 1945, a bipolar order became the primary characteristic of the international states system during the so-called "Cold War". The result was an evolving bipolar states system that featured increasingly strong norms such as the illegality of war, national self-determination and with it the principle of de-colonization. The bipolar structure also provided small states, old and new, with a ready-made security arrangement: Small states could and frequently did choose the security provided them by a superpower in return for joining its ideological 'camp,' the Eastern or Western bloc. All in all, the Cold War international system constituted a rather supportive environment for small states. As a result, small states proliferated dramatically. Again the states system impacted heavily on the survivability of new and existing small states. In fact, this period demonstrates well the link between the numbers of small states and the key features of the 
international states system. During the Cold War, small states in general enjoyed a comparatively high level of structural resilience.

Today, two developments stand out. First, the proliferation of small states appears to have come to an end-for now at least. Timor Leste is the only recent addition. Second, existing small states are, historically and structurally speaking, in a strong position, compared to earlier periods. Overall, there exists a high level of structural resilience among small states in the early $21^{\text {st }}$ century. The norm of the illegality of war may in fact have already developed into law. Moreover, the norm of self-determination appears to have evolved to a norm of 'continuing existence,' i.e., a norm that after the actual creation of a state, its existence cannot be questioned or reversed anymore. Furthermore, international organizations and multilateral diplomacy are key features of the contemporary international system. Taken together, these elements constitute an environment that is beneficial to the survival of small states, even if the system appears not to lend itself to a further proliferation of small states at the moment. However, the lack of small state proliferation could be either a temporary phenomenon or due to factors outside the scope of this study. Regardless, small states are surviving in large numbers at the beginning of the $21^{\text {st }}$ century, and their resilience to threats to their survival seems due in no small part to the international system in which they exist.

In sum, in different types of international systems-the balance of power, the concert system, the $20^{\text {th }}$ century's systems of collective security, bipolarity and the emergence of strong norms-small states are able to generate various degrees of systemic resilience. It is to a good extent through such a mechanism that the number of small states in the international system is affected. On the other hand, this means that the number of small states is to a considerable extent systemically determined. The German historian Heinrich v. Treitschke talked about precisely this mechanism of dynamic when he observed that "Switzerland, Belgium, and Holland survive not positively, through their own strength, but negatively, as a function of the European balance-of-power" (Handel 1981, 210).

\section{CONCLUSION}

The discussion of the changing number of small states over time above points to the validity of two major claims alluded to in the introduction. First, the number of small states in the international system of states, and thus the composition of the states system, has varied significantly over the course of the existence of the Westphalian states system. And neither was there a long, gradual decline nor the commonly assumed 'historic' rise of small states in the $1950 \mathrm{~s}$ and 1960s. If put in proper historical perspective, a quite different and more complex picture emerges. Second, major trends regarding the numbers of small states 
in the system can be identified and in fact matched to broad evolutionary shifts in the set-up of the states system itself. Put differently, the survival of small states can be linked to systemic changes in international relations. Hence the argument that small states may enjoy higher or lower degrees of systemic resilience, depending on the actual international states system in place at the time.

In addition, for the 360 years under investigation here, the development of the SSI generally parallels changes in the total number of small states. Thus, it can be observed that the expansion of the geographic states system did not distort the 'story' of the proliferation of the small state.

As the detailed investigation into the survival and proliferation of small states over time provided above has indicated, three broader trends regarding the structural resilience of small states can be identified. These major trends correspond to the three major periods identified earlier. From the time of the inception of the Westphalian states system in 1648 to the French Revolutionary Wars, small states fared rather well: Although their numbers eroded slowly, small states existed in large numbers. In fact, never again has the international states system contained small states in these numbers, neither in absolute not in relative terms.

The environment of the $19^{\text {th }}$ century proved to be detrimental to the survival of small states. After a period of recovery in the first half of the century, the numbers of small states crashed in the 1860s and early 1870s, due to Italian and German national unification; the numbers continued to decrease for the rest of the century, however, and reached their historic low just after the turn of the century. While the small state recovered somewhat after Versailles and during the interwar period, it was not until the Cold War was well under way that the numbers of small states increased steeply over a number of decades. The recent 'rise' of the small state, however, appears to have come to and end already. Although the current state system seems to support the small state at present numbers, a further significant increase in the number of small states appears unlikely. However, by the same token, the fact that the total and absolute numbers of small states has remained essentially flat also seems to indicate a significant measure of systemically generated resilience to threats to their survival.

In sum, the first period was characterized by a high and fairly stable number of small states. One might argue that small states enjoyed a high degree of systemically generated resilience. The experience of the small state in the $19^{\text {th }}$ century was almost the opposite of the one in the previous period. The number of small states fell continuously and at times dramatically. Small states during this period seemed to have obtained little resilience to threats to their survival. The third period, the $20^{\text {th }}$ century, saw first stabilization and then a dramatic recovery of the number of small states. The second half of the $20^{\text {th }}$ century in particular witnessed a rapid proliferation of small states. In this period, small 
states appeared to have regained a considerable degree of resilience that could threaten their survival and benefitted from an international system that was supportive of increasing numbers of small states. In other words, the 'story' of small states proliferation since 1648 is one of an initial high, a long and deep fall, and an impressive rise.

The findings presented here broaden the discussion of the survival of small states in two ways. First, the study extends the time-horizon. Previously, only data regarding the number of small states in the states system starting in 1919 was available for study. Second, a first, overall analysis of the data leads to the conclusion that the changes in the states system's composition of small and larger states have in fact been more frequent and complex than previously assumed.

Finally, I suggest that the changes in numbers of small states can be matched with changes of the overall system structure. Although further research is needed to identify causality more clearly, I maintain that the discussion above demonstrates a general and relevant match between the system and the proliferation of the small state. In fact, a picture emerges in which the states systems and the larger trends in the number of small states in fact track each other. In other words, I am suggesting that small states' systemic resilience is linked largely to the particular states system. The level of systemic resilience then factors prominently in explaining the rise and fall in the number of small states over time.

\section{REFERENCES}

Black, Jeremy. 2002. European International Relations 1648-1815. Houndmills: Palgrave.

Briguglio, Lino, Gordon Cordina, Nadia Farrugia, and Constance Vigilance, eds. 2008. Small States and the Pillars of Economic Resilience. Commonwealth Secretariat.

Commonwealth Advisory Group for Updating the Vulnerability, Report. 1997. A future for small states : overcoming vulnerability : report by a Commonwealth Advisory Group. London: Commonwealth Secretariat.

Enriquez, Juan. 1999. Too Many Flags? Foreign Policy 116(fall): 30-49.

Griffiths, Richard T., and Helge O. Pharo. 1995. Small States and European Integration. Literature Survey and Evaluation, Working Paper No. 19/95, ARENA Advanced Research on the Europeanisation of the Nation-State. Oslo.

Gross, Leo. 1948. The Peace of Westphalia, 1648-1948. The American Journal of International Law 42: 20-41.

Hafiz, M. Abdul, and Abdur Rob Khan, eds. 1987. Security of Small States. Dhaka: The UP Limited. 
Handel, Michael. 1981. Weak, States in the International System. Totowa, NJ: Frank Cass.

Henrikson, Alan K. 1999. Small States in World Politics: The International Political Position and Diplomatic Influence of the World's Growing Number of Smaller Countries. Paper prepared for the Joint Commonwealth Secretariat / World Bank Task Force Conference on Small States, St. Lucia, February 17, 1999.

. 2001. A Coming 'Magnesian' Age? Small States, the Global System, and the International Community. Geopolitics 6(3): 49-86.

Horsman, Mathew, and Andrew Marshall. 1994. After the Nation-State. London: Harper Collins Publishers.

Hughes, Barry B. 1991. Continuity and Change in World Politics: The Clash of Perspectives. Englewood Cliffs, NJ: Prentice Hall.

Kisanga, Eliawony J, and Sarah Jane Dancie, eds. 2007. Commonwealth Small States, Issues and Prospects. London: Commonwealth Secretariat.

Luard, Evan. 1968. Conflict and Peace in the Modern International System. Boston: Little, Brown and Company.

Maass, Matthias. 2003. Small But Plentiful, The Proliferation of Small States in the International System of States, 1648-2002. Dissertation, The Fletcher School of Law and Diplomacy, Tufts University, Medford, MA. . 2009. The elusive definition of the small state. International Politics 46(1): $65-83$.

Morgenthau, Hans J. 1967. Politics among Nations, The Struggle for Power and Peace. $4^{\text {th }}$ ed. New York: Alfred A. Knopf.

Pufendorf, Samuel. 1934. De Jure Naturae et Gentium Libri Octo. trans. C. H. Oldfather and W. A. Oldfather. Vol. 2 of The Classics of International Law. ed. James Brown Scott. Oxford: Clarendon Press.

Rothstein, Robert L. 1968. Alliances and Small Powers, Institute of War and Peace Studies of the School of International Affairs of Columbia University. New York: Columbia UP.

Shennan, J. H. 1995. International Relations in Europe 1689-1789 eds. E. J. Evans and P. D. King, Lancaster Pamphlets. London: Routledge.

Singer, David, and Melvin Small. 1972. The Wages of War, 1816-1965. New York: Wiley. 